\title{
Prevention of HBV Recurrence after Liver Transplant: A Review
}

\author{
Myra Nasir* ${ }^{1,2}$ and George Y. Wu ${ }^{1}$ \\ ${ }^{1}$ Department of Medicine, Division of Gastroenterology-Hepatology, University of Connecticut Health Center, Farmington, CT, \\ USA; ${ }^{2}$ Department of Medicine, Division of Gastroenterology-Hepatology, University of Connecticut Health Center, Farmington, \\ $C T$, USA
}

\begin{abstract}
Globally, hepatitis B virus (HBV) infection is recognized as a major risk factor for the development of hepatocellular carcinoma, and HBV-induced liver failure is one of the leading indications for liver transplantation. Until about two decades ago, liver transplantation in patients with chronic HBV infection was a relative contraindication, due to high risk of viral replication with the use of immunosuppressants which could result in graft infection. In the 1990s, hepatitis B immunoglobulin (HBIg) use significantly reduced the risk of graft infection, improving outcomes of liver transplant in patients with chronic HBV infection. However, very high costs, especially with the need for long-term use, became a major concern. With the advent of nucleos(t)ide analogs (NAs), there was less need for high-dose, long-term HBIg use to prevent HBV recurrence. Lamivudine was initially used but resistance soon became a major issue. This was followed by more potent NAs, such as entecavir and tenofovir, emerging as the more preferred agents. Additionally, the use of these antiviral agents (HBIg and/or NAs) have made it possible to use the grafts from donors with positivity for hepatitis B core antibody, allowing for expansion of the donor pool. Nevertheless, there is no consensus on management protocols, which vary significantly amongst centers. In this review, we appraise studies on management strategies used and the role of active vaccination in the prevention of HBV recurrence in post-liver transplant patients. Citation of this article: Nasir M, Wu GY. Prevention of HBV recurrence after liver transplant: A review. J Clin Transl Hepatol 2020;8(2):150-160. doi: 10.14218/JCTH.2020.00003.
\end{abstract}

\section{Introduction}

In the USA, hepatocellular carcinoma (HCC) and liver failure due to hepatitis $C$ are the most common indications for liver transplant (LT). ${ }^{1}$ However, worldwide, hepatitis B virus (HBV)

Keywords: Hepatitis B; Recurrence; Liver transplant; Vaccination Abbreviations: ADV, adefovir dipivoxil; cccDNA, covalently closed circular DNA; ETV, entecavir; FTC, emtricitabine; HBCAb, hepatitis B core antibody; HBCAg, hepatitis $B$ core antigen; $\mathrm{HBeAg}$, hepatitis $\mathrm{B}$ e antigen; $\mathrm{HBIg}$, hepatitis $\mathrm{B}$ immunoglobulin; HBsAb, hepatitis B surface antibody; $\mathrm{HBsAg}$, hepatitis $B$ surface antigen HBV, hepatitis B virus; HCC, hepatocellular carcinoma; LAM, lamivudine; LT, liver transplant; NA, nucleos(t)ide analog; SVR, sustained virologic response; TAF, tenofovir alafenamide; TDF, tenofovir disoproxil fumarate.

Received: 17 January 2020; Revised: 16 April 2020; Accepted: 27 April 2020

*Correspondence to: Myra Nasir, Department of Medicine, Division of Gastroenterology-Hepatology, University of Connecticut Health Center, Farmington, CT 06030 USA. Tel: +1-860-470-6616, Fax: +1-860-679-3159, E-mail: mnasir@uchc.edu infection is the major risk factor for development of HCC, and has remained the leading indication for LT in Asian countries. ${ }^{2}$ Until the 1990s, HBV infection was considered a relative contraindication to $L T$, due to high risk of graft infection and subsequent liver failure as a result of post-transplant immunosuppression. ${ }^{3}$ Positivity for hepatitis B surface antigen (HBsAg) and presence of HBV DNA in liver biopsies after transplantation of HBV-naïve donor liver was considered to be diagnostic for recurrence of HBV infection post-LT and was associated with poor long-term outcomes of those transplants. ${ }^{4}$

Over the past two decades, with the use of hepatitis $B$ immunoglobulin (HBIg) and oral antivirals, a significant reduction in post-transplant recurrence of HBV infection has been noted, allowing for successful LT in patients with chronic hepatitis $B .^{5}$ The goal of antiviral therapy is the suppression of HBV DNA and preferably achievement of sustained virologic response (SVR). HBIg can be used to neutralize viral particles by binding to $\mathrm{HBsAg}$, while nucleos(t)ide analogs (NAs) can be used to inhibit viral reverse transcriptase with consequent inhibition of HBV DNA replication. Combination of HBIg and NAs can also be used. However, there are no standardized protocols for the prevention of HBV recurrence after $\mathrm{LT}^{5}{ }^{5}$ In addition, the high cost of long-term HBIg use and resistance to certain NAs can limit their use, requiring alternate management strategies. Additionally, factors, such as presence of hepatitis $\mathrm{B}$ core antibody (HBCAb), ${ }^{6} \mathrm{HBsAg}$ or HBV DNA at the time of LT introduce varying degrees of risk of recurrence post-LT.

In this article, we review various regimens used for prevention of recurrence of HBV in post-LT patients.

\section{Definition of HBV recurrence}

The studies included in this article defined HBV recurrence as reappearance of $\mathrm{HBsAg}$ in patients on anti-HBV treatment who initially had clearance of this marker, unless specified otherwise.

\section{Clinicopathological features of HBV recurrence post-LT}

Lerut et al. ${ }^{7}$ reported time to HBV recurrence after LT ranges between 15 and 2615 days (median of 145 days). In this study, 3/16 patients with recurrence developed fibrosing cholestatic hepatitis and died within a year of LT.

HBV recurrence can result in varying degrees of pathological damage, including mild self-limited hepatitis, chronic active hepatitis, fulminant hepatitis, and fibrosing cholestatic hepatitis. $^{8}$

Zhang et al. ${ }^{8}$ enrolled 184 patients who had received LT for HBV-related liver disease in a study, out of which 11 patients 
developed HBV recurrence. In the early stages, hepatocyte swelling, ballooning degeneration, small necrosis, periportal inflammatory cell infiltration was seen on tissue. Five patients died, while the remaining six received adefovir dipivoxil (ADV) and entecavir (ETV), resulting in improvement in histology that had manifested by a decrease in the number of liver cells showing positivity for $\mathrm{HBsAg}$ and hepatitis $\mathrm{B}$ core antigen (HBcAg), fewer nuclei with detectable HBV DNA, inconspicuous fibrous tissue proliferation, and decreased inflammation and hepatocyte swelling. Of the five patients who died, four received lamivudine (LAM) monotherapy. They developed fibrosing cholestatic hepatitis characterized by fibrous tissue development in periportal areas, bile duct hyperplasia and extensive cellular and canalicular cholestasis.

In a study including 45 patients with $\mathrm{HBsAg-positive} \mathrm{status}$ who received LT and HBV treatment with HBIg or recombinant alpha interferon, Demetris et al. ${ }^{9}$ demonstrated recurrent HBV infection in 33 patients. Out of these 33, 11 died due to multiorgan failure as a complication of HBV recurrence, 3 died due to recurrence of $\mathrm{HCC}$, and 1 died due to intracerebral hemorrhage.

Studies including a larger patient population who experienced $\mathrm{HBV}$ recurrence post-LT are required to further investigate the clinical and pathological implications of HBV recurrence after LT.

\section{Mechanism of HBV recurrence after LT}

Covalently closed circular DNA (cccDNA) is a template for transcription for hepatitis B viral RNA (Fig. 1). When grafts from donors with history of HBV infection are used, the graft hepatocytes may contain cccDNA, accompanied by its replicative potential. ${ }^{10}$ No currently approved drugs target the elimination of CCCDNA, resulting in risk of HBV recurrence.

It is proposed, however, that certain genotypes of HBV may have higher risk of causing recurrence. Devarbhavi et al. ${ }^{11} \mathrm{dem}-$

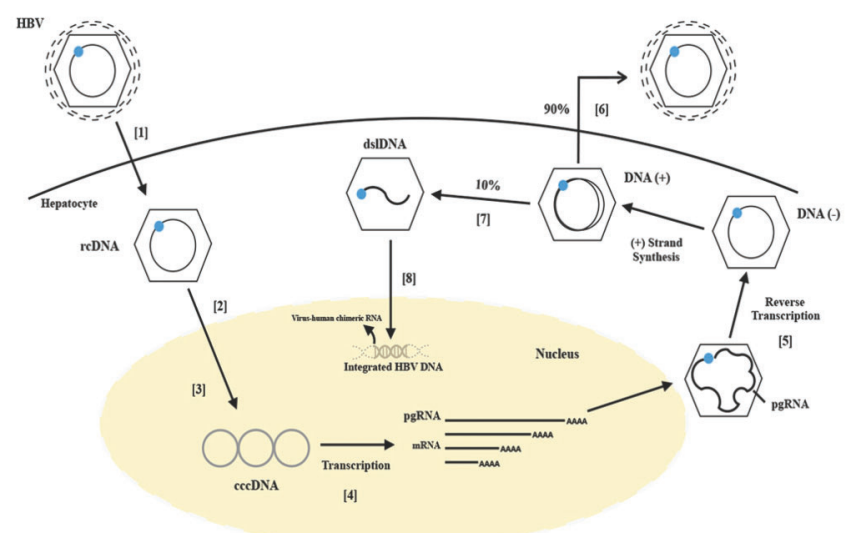

Fig. 1. Simplified illustration of HBV cell cycle. ${ }^{16}$

The viral envelope proteins, such as $\mathrm{HBsAg}$, bind to host cell surface receptors, resulting in endocytosis of the hepatitis B virion into the host cell. ${ }^{1}$ The nucleocapsid releases relaxed circular HBV DNA (rcDNA) into the nucleus, 2 which is converted into covalently closed circular double stranded DNA (cccDNA). ${ }^{3}$ The cccDNA is a template for transcription of viral RNA. ${ }^{4}$ The transcribed pregenomic RNA (pgRNA) undergoes reverse transcription, ${ }^{5}$ forming rCDNA. At the endoplasmic reticulum, virions assemble (not shown in diagram $)^{6}$ and the mature virions are excreted from the host cell via budding. Occasionally $(10 \%)$, double-stranded linear DNA (dsIDNA) is produced, ${ }^{7}$ which can be integrated into the host genome. ${ }^{8}$ onstrated such potential to be present in genotype $D$, with a higher mortality risk as well, when compared with genotype A.

Jiang et al. ${ }^{12}$ analyzed the genomic DNAs of LT recipients who suffered from HBV-related liver disease and found that recipients with CTLA-4 +49 GG genotype had a lower risk of recurrence than those without the genotype $(p=0.032)$. This finding suggests that the genetic variations of recipients may be associated with the risk of recurrence.

Occult HBV infection is defined as HBsAg-negative status with detectable HBV DNA in serum or liver specimen (Fig. 2). Ferrari et al. ${ }^{13}$ found $4.4 \%$ of patients with cirrhosis undergoing LT to have occult HBV infection, according to results from a nested polymerase chain reaction assay. However, this study was conducted in Brazil, where the prevalence of HBV infection is low, limiting its applicability to other parts of the world with higher HBV prevalence. Nevertheless, this study manifests the risk of HBV recurrence post-LT due to occult infection.

LT patients often undergo immunosuppressive therapy, which may lead to increased viral replication. In vitro studies have shown direct stimulation of HBV replication by immunosuppressants, especially by steroids which can act on the corticosteroid response element in the HBV DNA, resulting in increased transcription of the HBV DNA. ${ }^{14,15}$ Immunosuppressive effect on the host innate and adaptive immune cells may also result in unopposed viral replication, followed by an aggressive immune response after the immunosuppressants are withdrawn, ultimately resulting in liver injury. ${ }^{14}$

\section{Prevention regimens}

\section{HBIG monotherapy}

The proposed mechanism of action of HBIg includes binding to the viral particles and $\mathrm{HBSAg}$, resulting in neutralization and

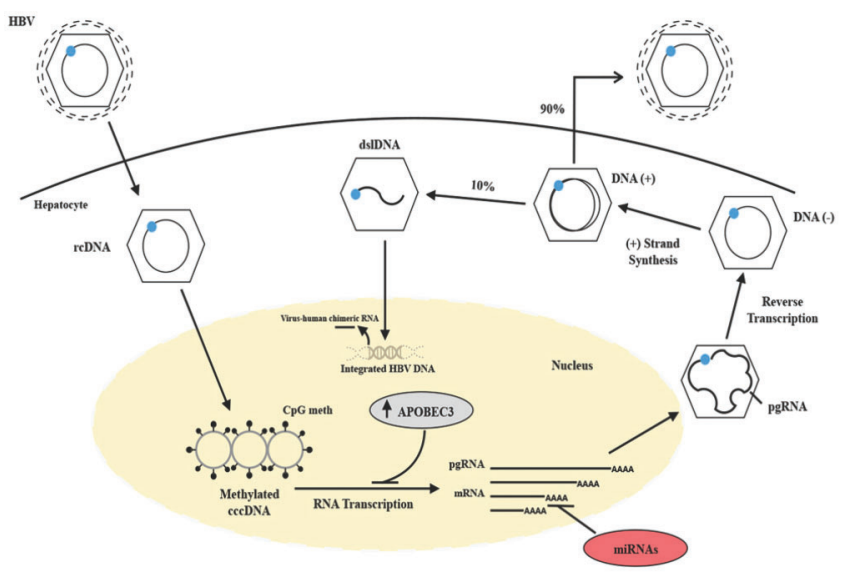

Fig. 2. Selected proposed mechanisms involved in occult HBV infection. ${ }^{17,18}$

Methylation of covalently closed circular DNA (cccDNA) correlates with decreased HBV replication. Chronic HBV infection can upregulate the production of $A P O B E C$ genes, which is associated with hyperedited HBV genome and decreased HBV replication. MicroRNAs are small, non-coding molecules found in viruses that function in RNA silencing and post-transcriptional mechanisms which may be involved in decreasing viral replication. These mechanisms do not result in complete viral suppression and low-level replication may persist. These mechanisms may be reversible, resulting in overt infection. 
thereby preventing viral attachment to the hepatocytes. Infected hepatocytes express $\mathrm{HBsAg}$, which the HBIg binds to, resulting in cell-mediated cytotoxicity. ${ }^{19}$ Monoclonal HBIg has been shown to decrease secretion of wild-type HBsAg but not of mutant HBsAg from infected cells, suggesting that HBIg may be internalized in hepatocytes. ${ }^{20}$ With the use of HBIg, McGory et al. ${ }^{21}$ found a significant improvement in patient survival at an average follow up period of 22.7 months, with the prevention of $\mathrm{HBV}$ recurrence in $>82 \%$ of patients post-transplant, regardless of the presence or absence of hepatitis $B$ e antigen ( $\mathrm{HBeAg}$ ) or HBV DNA pre-transplant. The dose of HBIg required varied amongst the patients and was individualized. Patients who were $\mathrm{HBeAg}$-positive were noted to require higher doses to maintain the serum anti-HBs titer at a desired level. High doses and long-term HBIg were used in many patients due to risk of late recurrence, with one out of twenty-seven patients developing reappearance of HBsAg at 1.5 years after LT. Though this is a single-center study, including a small population, larger studies have also shown favorable outcomes with the use of HBIg. However, HBV DNA detectability is a major risk factor for recurrence, but this information was only available for seven out of the twenty-seven patients in this study.

Samuel et al. ${ }^{22}$ conducted a multicenter study including 372 patients. They reported a recurrence of HBV infection in about $75 \%$ of the patients who received no or only short-term (2 months post-LT) HBIg. With the use of long-term (6 months or more) HBIg, they showed a 3-year actuarial risk of recurrence of about $56 \%$, compared with about $78 \%$ for patients receiving no immunoprophylaxis. Though this is a retrospective analysis, it includes a large patient population from 17 European centers.

The mechanism of recurrence may include saturation of HBIg by high viral count or mutations in the HBsAg due to emergence of antibody-induced escape HBV mutants resulting in inadequate treatment. ${ }^{23-26}$ Mutations mostly occur at codon 145 of HBsAg, leading to a glycine-to-arginine substitution, which has been seen in post-LT patients receiving $\mathrm{HBIg}$ and HBV vaccine recipients. ${ }^{25,27}$

In patients with renal failure, the risk of worsening of the kidney function appeared to be a major concern with ADV and tenofovir disoproxil fumarate (TDF). Additionally, HBIg was administered intravenously, which can be quite inconvenient for long-term treatment. The safety and efficacy of subcutaneous HBIg monotherapy was investigated in a prospective study, showing $100 \%$ success rate (no HBV recurrence) after a mean follow-up period of $36 \pm 5$ months, without worsening of kidney function; this suggested that HBIg monotherapy was not only highly effective in preventing recurrence but also not associated with deleterious renal effects, which is a risk with the use of certain NAs. ${ }^{28}$ Target antibody levels for patients at high risk of recurrence (such as those positive for HBV DNA pre-LT) was $\geq 200 \mathrm{IU} / \mathrm{L}$, and those at lower risk was $\geq 150 \mathrm{IU} / \mathrm{L}$. However, it is important to note that this study included only 43 patients, all Caucasian in origin, all HBsAg- and HBV DNA-negative at inclusion. Most of these patients received a combination of $\mathrm{HBIg}$ (intravenous) and NA initially after LT, which was switched to HBIg IV monotherapy after 1 year, followed by a switch to subcutaneous HBIg. Randomized controlled trials, with larger patient populations, are required to support the findings in this study. Moreover, it is important to note that renal failure has now become less of a concern with the advent of tenofovir alafenamide (TAF).

Though the use of HBIg has been reported to prevent recurrence by neutralizing $\mathrm{HBsAg}$, its failure may be attrib- uted to its inability to inhibit viral replication, ${ }^{29}$ which argues against the use of HBIg alone. Antibody-induced escape HBV mutants can arise, resulting in failure of HBIg treatment. The high cost of HBIg is also a major concern, especially with long-term, high dosage use. Additionally, it has been reported to cause mercury toxicity, ${ }^{23,30}$ due to thimerosal in the HBIg treatment, when long-term and high-dose HBIg is used. HBIg is administered parenterally and is associated with severe back pain, anaphylactic reactions, tremors and hypotension. Given these concerns and the fact that there was still a risk of HBV recurrence, albeit significantly lower than without any prophylaxis, alternative management strategies, including the use of NAs, have increased in favor.

\section{NAs with or without HBIg}

\section{Nucleoside analogs}

LAM/ADV plus HBIg: LAM is a nucleoside analog which inhibits the reverse transcriptase of $\mathrm{HBV}$, thereby inhibiting viral replication. Mutimer et al. ${ }^{31}$ used LAM monotherapy to treat HBV prior to LT and continued it as prophylaxis against recurrence. Ten patients were included and started on LAM at least 4 weeks prior to LT. Recurrence of graft infection with LAM-resistant virus was observed in $50 \%$ of the patients. Recurrence was mainly seen in patients with high viral replication and resistant viremia even prior to LAM exposure. This study suggests LAM monoprophylaxis was inadequate and highlighted the importance of LAM resistance. The use of $\mathrm{HBIg}$ in combination was proposed to neutralize the LAMresistant species. However, this was a small study, including only 10 patients.

A larger, multicenter USA-Canadian trial of LAM demonstrated that $60 \%$ of the patients remained HBsAg-negative at 12 or more weeks post-transplant with the use of LAM alone. ${ }^{32}$ In this study, $47 \mathrm{HBsAg}$-positive patients were included. LAM was started pre-transplant and was continued for 5 years with the first test for recurrence or $\mathrm{HBsAg}$-positive status at 12 weeks post-LT. An important finding in this study was that $80 \%$ of HBV DNA-positive patients at baseline had recurrence at the $156^{\text {th }}$ week of treatment, as compared with $0 \%$ of patients who were HBV DNA-negative at baseline. Though this is a large study with a long follow-up period, the longterm consequences of LAM resistance resulting in HBV recurrence and other clinical outcomes were not investigated.

Other, smaller studies on combination of HBIg with LAM showed significant reductions in the recurrence, to 3-4\% $33-35$ (Table 1). Lower doses of HBIg were used, ${ }^{36}$ possibly reducing cost compared with HBIg monotherapy and prophylaxis. It is important to note that in one study with $0 \%$ recurrence, only six patients were included, all of who were HBV DNA-negative at the time of LT. ${ }^{34}$ In the other two studies with higher rates of recurrence, patients with positive HBV DNA at the time of LT were included. ${ }^{33,35}$ This raises the concern that the HBIg and LAM combination may only be safe to use in patients with low risk of $\mathrm{HBV}$ recurrence, limiting its use.

Beckebaum et al. ${ }^{37}$ recruited 371 patients in a study to evaluate the recurrence of HBV infection post-LT with longterm HBIg use. Prior to LT, 217 patients received an NA, whereas 347 received an NA post-LT. LAM was the most frequently used NA. The population of all patients who received HBIg included 299/371 who received intravenous HBIgB, 236 of which were switched to subcutaneous HBIg, and 136 patients who received another HBIg product. The total 
Nasir M. et al: HBV recurrence post-liver transplant

Table 1. Main results of studies using nucleoside or nucleotide analogs with hepatitis B immunoglobulin

\begin{tabular}{|c|c|c|c|c|c|c|}
\hline Reference & Patients, $n$ & $\begin{array}{l}\text { Median } \\
\text { follow-up, } \\
\text { months }\end{array}$ & NA & $\begin{array}{l}\text { Patients } \\
\text { with } \\
\text { detectable } \\
\text { HBV DNA } \\
\text { at LT, } n\end{array}$ & HBIg use & $\begin{array}{l}\text { HBV } \\
\text { recurrence }\end{array}$ \\
\hline Yao, et al. ${ }^{33}$ & 10 & 15.6 & LAM & 2 & $\begin{array}{l}45 \mathrm{~mL}(10,000 \mathrm{U}) \text { IV HBIg } \\
\text { daily for } 7 \text { days, then } 5 \mathrm{mg} \\
\text { IM HBIg for weekly for } 4 \\
\text { weeks, then every } 3 \\
\text { weeks }\end{array}$ & $10 \%$ \\
\hline $\begin{array}{l}\text { Yoshida, } \\
\text { et al. }{ }^{34}\end{array}$ & 6 & 44.3 & LAM & 0 & $\begin{array}{l}2170 \text { IU IM intraop. and } \\
\text { daily for } 14 \text { days, then } \\
\text { twice weekly, then every } \\
2-4 \text { weeks. By } 1 \text { year } \\
\text { post-LT }\end{array}$ & $0 \%$ \\
\hline $\begin{array}{l}\text { Marzano, } \\
\text { et al. }{ }^{35}\end{array}$ & 25 & 31 & LAM & 7 & $\begin{array}{l}46,500 \text { IU in first mo. } \\
\text { Post-LT, then } 5000 \mathrm{IU} / \\
\text { month. }\end{array}$ & $4 \%$ \\
\hline $\begin{array}{l}\text { Beckebaum, } \\
\text { et al. }{ }^{37}\end{array}$ & 371 & $78^{a}$ & $\begin{array}{l}\text { LAM } \\
\text { or } \\
\text { LAM/ } \\
\text { ADV }\end{array}$ & $101 / 239^{b}$ & $\begin{array}{l}\text { IV HBIgB: } 238 \text { IU daily } \\
\text { Sc HBIg: } 71 \text { IU daily } \\
\text { Other HBIg: } 71 \text { IU daily }\end{array}$ & $4.3 \%$ \\
\hline $\begin{array}{l}\text { Darweesh, } \\
\text { et al. }{ }^{42}\end{array}$ & $\begin{array}{l}44 \text { (18 in ETV+HBIg } \\
\text { group, } 14 \text { in other NA } \\
+ \text { ETV+HBIg group, } 10 \text { in } \\
\text { other NA+HBIG group } \\
\text { and } 2 \text { in ETV+other NA } \\
\text { group) }\end{array}$ & $\sim 96$ & $\begin{array}{l}\text { ETV } \\
\text { Other } \\
\text { NA } \\
\text { (TDF } \\
\text { or } \\
\text { ADV) }\end{array}$ & 38 & $\begin{array}{l}2000 \text { IU IM in anhepatic } \\
\text { phase, then } 1600 \text { IU daily } \\
\text { till negative HbsAg after } \\
\text { LT and HBsAb >500 IU/L, } \\
\text { then } 800 \text { IU/week with } \\
\text { subsequent decreasing } \\
\text { HBsAb titer goal over } 12 \\
\text { months }\end{array}$ & $\begin{array}{l}\text { ETV+HBIg: } \\
0 \% \\
\text { ETV+other } \\
\text { NA+HBIg: } \\
0 \% \\
\text { Other NA } \\
+ \text { HBIg: } \\
30 \%\end{array}$ \\
\hline $\begin{array}{l}\text { Shen, } \\
\text { et al. }{ }^{43}\end{array}$ & $\begin{array}{l}5333 \text { total Group A: } \\
n=4684, \text { received HBIg } \\
\text { +LAM Group B: } n=491, \\
\text { received HBIg+ETV } \\
\text { Group C: } n=158, \text { received } \\
\text { HBIg and ADV }\end{array}$ & $\sim 42.1$ & $\begin{array}{l}\text { LAM, } \\
\text { ETV } \\
\text { and } \\
\text { ADV }\end{array}$ & $\begin{array}{l}\text { Group A: } \\
1024 \\
\text { Group B: } \\
40 \text { Group } \\
\text { C: } 17\end{array}$ & $\begin{array}{l}2000 \text { IU in anhepatic } \\
\text { phase, followed by } 800 \text { IU } \\
\text { daily for next } 6 \text { days, then } \\
\text { weekly for } 3 \text { weeks, then } \\
\text { monthly }\end{array}$ & $\begin{array}{l}\text { At } 5 \text { years } \\
\text { Group A: } \\
4.7 \% \\
\text { Group B: } \\
1.5 \% \\
\text { Group C: } \\
4.4 \%\end{array}$ \\
\hline
\end{tabular}

${ }^{\mathrm{a}}$ Mean follow up period

$\mathrm{b}_{239}$ patients out of 371 had HBV DNA serologies available.

Abbreviations: ADV, adefovir dipivoxil; ETV, entecavir; HBIg, hepatitis B immunoglobulin; HBsAb, hepatitis B antibody; HBV, hepatitis B virus; IM, intramuscular; intraop., intraoperative; IV, intravenous; LAM, lamivudine; NA, nucleos(t)ide analog; sc, subcutaneous.

durations of treatment were 8993,8379 and 5392 months respectively. The mean follow-up time was $6.8 \pm 3.5$ years. Recurrence was noted in $4.3 \%$ of the patients (16/371), out of which $5 / 16$ had discontinued HBIg and $7 / 16$ had anti-HBs levels of less than $100 \mathrm{IU} / \mathrm{L}$.

Though this study had an adequate patient population with a long follow-up period, its retrospective design is a limitation. Since it is a non-interventional study, anti-HBs levels were not routinely documented.

ADV had a better resistance profile compared to LAM. ${ }^{38}$ In a systematic review, Cholongitas et al. ${ }^{39}$ showed recurrence rates of as low as $2 \%$ in patients who received ADV and HBIg combination regimen with or without LAM, significantly lower than with LAM alone $(p=0.024)$. They also demonstrated ADV prophylaxis, without HBIg, with or without use of LAM ( $0 \%$ recurrence), to be superior to LAM monoprophylaxis (recurrence of $25.4 \%$ ). However, the patient population receiving ADV prophylaxis without HBIg was small (47 patients) and the post-LT follow-up period was short (median of 16 months). Larger studies with longer follow-up periods are required to support these findings. Nevertheless, high cost with risk for development of viral resistance and nephrotoxicity has limited the use of ADV. ${ }^{40}$

LAM/ADV versus ETV and/or tenofovir: According to the AASLD 2018 guidelines, ETV, TDF and TAF are preferred over LAM and ADV due to their higher potency and lower rates of drug resistance. ${ }^{41}$ In a recent retrospective study including 44 patients ( $86 \%$ with positivity for HBV DNA at the time of LT), none of the 34 patients receiving the combination of ETV with HBIg tested positive for HBsAg in the 8 year follow-up period. ${ }^{42}$ However, four out of the fourteen patients on ETV plus another NA (TDF/ LAM) with HBIg developed recurrence with positive $\mathrm{HBsAg}$, which eventually converted to $\mathrm{HBsAb}$ towards the end of the 8 year follow-up period. There was no evidence of clinically significant hepatitis or presence of HBV DNA in these patients. 
Shen et al. ${ }^{43}$ used a national database to demonstrate better efficacy of ETV/HBIg prophylaxis compared to LAM/ HBIg use with the 1-year, 3-year and 5-year recurrence rates of $\mathrm{HBV}$ of $0.5 \%, 1.5 \%$ and $1.5 \%$ with ETV/HBIg, respectively compared to $1.7 \%, 3.5 \%$ and $4.7 \%$ with LAM/HBIg $(p=0.023)$. Before LT, patients with positive HBV DNA received one NA daily, which was then continued post-LT.

Although both the studies mentioned above were retrospective, they included adequate population size with long follow-up periods, both showing very low recurrence rates.

LAM/ADV with HBIg withdrawal: Studies have shown that the use of NAs has made it possible to eventually withdraw HBIg in patients who were initially started on a combination regimen (Table 2). Now, the American Association for the Study of Liver Diseases, the European Association for the Study of the Liver and the Asian Pacific Association for the Study of the Liver guidelines include an option of HBIg withdrawal post-LT in patients with low risk of recurrence, such as those with low or undetectable HBV DNA levels prior to transplant or without resistant HBV. ${ }^{44-46}$

Until 2010, the standard prophylactic regimen included indefinite HBIg and LAM. In 2011, Saab et al. ${ }^{47}$ maintained 61 patients on a combination of HBIg and LAM for 12 months postLT and then withdrew HBIg. Three months before withdrawing HBIg, a NA (TDF or ETV) was added to the regimen. Within a mean follow-up period of around 15 months after conversion to oral antivirals only, two patients $(3.3 \%)$ presented HBV recurrence, which was similar to the recurrence rate when using LAM and long-term HBIg. ${ }^{48}$ In addition, this regimen was noted to be more cost effective than the standard regimen using lifelong HBIg. However, for dual nucleoside and nucleotide analog combinations renal toxicity was a major concern. In one of the two cases with the recurrence in this study, dose of oral antivirals had to be decreased due to renal injury which may have led to the recurrence. Moreover, the study population only included patients with low risk of recurrence, such as undetectable HBV DNA at the time of transplant and no viral co-infection.

ETV/TDF/TAF with HBIg withdrawal: Lee et al. ${ }^{5}$ administered 10,000 IU during the anhepatic phase and during surgery followed by 2000 IU daily for a week postoperatively. Two hundred and thirty-two patients were divided into groups labeled $\mathrm{Q}$ and $\mathrm{S}$ ( those with quick decline of antiHBs titers ( $<200 \mathrm{IU} / \mathrm{mL} ; 1$-month post-operation) and those with slow decline of the titers ( $>200 \mathrm{IU} / \mathrm{mL} 1$-month postoperation) respectively. From postoperative day 1 , NA (ETV or TDF) was started and continued indefinitely. Patients in the $\mathrm{Q}$ group received $\mathrm{HBIg}$ boosters to maintain HBIg titers. HBV recurrence was found to be $18.9 \%$ in group $\mathrm{Q}$ and $7.3 \%$ in group S. This study suggests using long-term HBIg in patients with quick decline of HBIg levels. Group Q had patients with higher MELD scores and higher HBV viral loads compared with group S, representing important confounders. However, multivariate analysis was done which did not show these variables to be significantly different.

In a single-center, retrospective study, LAM, ETV, TDF, and TAF were used alone or as two in combination to study the impact of these drugs on the renal function. ${ }^{49} \mathrm{HBIg}$ was used for a mean of 633 days (standard deviation ( \pm 552 days) in 79 patients with the NA(s) after which HBIg was stopped and the $\mathrm{NA}(\mathrm{s})$ were continued. Patients were followed up for a mean of 1723 days (standard deviation $( \pm 1164)$ after HBIg withdrawal. There was no significant change in the serum creatinine or glomerular filtration rate compared before and after using TAF but there was an increase of $0.55 \mathrm{mg} / \mathrm{dL}$ of serum creatinine in patients who were never on $\operatorname{TAF}(p<0.05)$. Up to $6 \%$ of patients on TAF experienced an increase in chronic kidney disease stage compared with $23 \%$ of the patients who received NA(s) other than TAF. However, there was no standard immunosuppression protocol used in the patient population included in this study. Immunosuppressants are known to cause renal dysfunction, which could have been a significant confounding factor regarding observed changes in renal function. This factor was not adjusted for in this study.

\section{NA without HBIg}

A prospective, multicenter study used the combination of ADV and LAM and showed prevention of HBV recurrence post-LT in all patients after a median follow-up period of 5 years, with the median time of HBsAg undetectability being 7 days. HBV recurrence in this study was specified as reappearance of both HBsAg and HBV DNA. Of the 20 patients, 13 tested positive for HBV DNA at the time of LT (1 patient was not tested). HBIg was given during the anhepatic phase and daily for only 7 days after LT, whereas LAM and ADV were continued long term. Of note is the fact that $>50 \%$ of the patients were at high risk of recurrence (i.e. having detectable HBV DNA at the time of transplant). ${ }^{50}$ However, this study included a small study population without a randomized control group and the risk of viral resistance with LAM and ADV is still a concern.

Stravitz et al. ${ }^{51}$ demonstrated successful substitution of HBIg/LAM combination with TDF/emtricitabine (FTC) combination, preventing post-LT HBsAg recurrence in $18 / 21$ patients and HBV DNA recurrence in 20/21 patients. In the latter case, recurrence occurred in the patient who was noncompliant, and after resuming TDF/FTC, HBsAg and HBV DNA became undetectable. This allowed for cost savings of about $\$ 12,500$ per year, as compared to HBIg/LAM regimen. However, it must be noted that the $13 / 21$ had negative HBeAg and 8/18 had undetectable HBV DNA at the time of LT, making the population included in this study largely at low risk for recurrence.

Fung et al. ${ }^{52}$ studied the long-term outcome of ETV monotherapy post-LT in a larger cohort of 265 patients, with $>60 \%$ of patients with detectable HBV DNA at the time of LT, and demonstrated $\mathrm{HBsAg}$ clearance rate of $92 \%$ and $\mathrm{HBV}$ DNA undetectable rate of $100 \%$ at 8 years post-LT. Although this study suggests favorable outcomes with ETV monotherapy, six patients did receive an addition of tenofovir in addition or were switched to tenofovir due to concern for no or delated virologic response. In a large meta-analysis including 17 studies with a total of 7274 patients, ETV monoprophylaxis, when compared with LAM (odds ratio of 4.62), TDF (odds ratio of 1.11), ADV (odds ratio of 3.78), LAM+TDF (odds ratio of 2.00) and LAM+ADV (odds ratio of 2.83), was found to have the lowest probability of HBV recurrence, making it the most preferred oral agent for prophylaxis. ${ }^{53}$ However, a major limitation in this analysis is the lack of information on reappearance of HBV DNA after treatment in the studies included in this meta-analysis. Other sources of bias include different $\mathrm{HBIg}$ and antiviral protocols used in the studies.

In all studies mentioned above, NAs were continued indefinitely.

\section{Withdrawal of both HBIg and NA}

Recipients who have negativity for $\mathrm{HBeAg}$ and undetectable HBV DNA have been historically noted to have lower rates of 
Nasir M. et al: HBV recurrence post-liver transplant

Table 2. Main results of studies using HBIg/NA combination therapy with eventual withdrawal of HBIg

\begin{tabular}{|c|c|c|c|c|c|}
\hline Reference & $\begin{array}{l}\text { Patients, } \\
n\end{array}$ & $\begin{array}{l}\text { Median follow- } \\
\text { up, months }\end{array}$ & NAs & HBIg protocol & HBV recurrence \\
\hline Lee, et al. ${ }^{5}$ & 232 & 42.2 & Either LAM or ETV & $\begin{array}{l}10,000 \text { IU at anhepatic } \\
\text { phase and during surgery. } \\
2000 \text { IU daily for a week } \\
\text { post-LT }\end{array}$ & $\begin{array}{l}12.1 \%(18.9 \% \\
\text { in group } Q \text { and } \\
7.3 \% \text { in group } \\
S), p=0.013\end{array}$ \\
\hline $\begin{array}{l}\text { Vasudevan, } \\
\text { et al. }{ }^{80}\end{array}$ & 18 & 60 & $\begin{array}{l}\text { LAM started at } 48 \mathrm{~h} \\
\text { after LT ( } 100 \mathrm{mg} \\
\text { daily). At } 12 \\
\text { months, HBIg } \\
\text { substituted by TDF. }\end{array}$ & $\begin{array}{l}800 \text { IU at anhepatic phase, } \\
800 \text { IU daily for a week post- } \\
\text { LT, then } 800 \text { IU twice weekly } \\
\text { for weeks } 2-4 \text { post-LT, then } \\
800 \text { IU monthly till } 12 \\
\text { months post LT }\end{array}$ & $11 \%$ \\
\hline Saab, et al. ${ }^{47}$ & 61 & $15.0( \pm 6.1)$ & $\begin{array}{l}\text { LAM or ETV and ADV } \\
\text { or TDF }\end{array}$ & $\begin{array}{l}\text { Standard protocol }{ }^{1^{\mathrm{a}}} \text { with at } \\
\text { least } 12 \text { months of IM HBIg }\end{array}$ & $3.3 \%$ \\
\hline Sabela, et al. ${ }^{81}$ & 338 & 72 & LAM & $\begin{array}{l}5000-10,000 \text { IU on post-LT } \\
\text { day } 0 \text {, then } 5000-10,000 \mathrm{IU} / \\
\text { day for } 1 \text { week, then } 1000 \\
\text { IU/week for } 1 \text { month, } \\
\text { followed by } 1000 \mathrm{IU} \text { at } \\
\text { different intervals to } \\
\text { maintain target HBsAb } \\
\text { target }\end{array}$ & $11 \%$ \\
\hline Manini, et al. ${ }^{82}$ & 77 & $\begin{array}{l}69 \text { (group A - } \\
\text { HBV } \\
\text { monoinfected), } \\
61 \text { (group B - } \\
\text { HBV/HDV } \\
\text { co-infection) }\end{array}$ & TDF or ETV & $\begin{array}{l}\text { Post- } 1998,5000 \text { IU IV } \\
\text { during anhepatic phase, } \\
\text { then } 5000 \text { IU right after } L T \text {, } \\
\text { then } 5000 \text { IU on alternate } \\
\text { days during week } 1 \text { post-LT, } \\
\text { then } 5000 \text { IU to keep HBsAb } \\
\geq 500 \text { till discharge, } 1-4000 \\
\text { IU to keep HBsAb } \geq 2501-6 \\
\text { months post-LT and } 1-4000 \\
\text { IU to keep HBsAb } \geq 100>6 \\
\text { months post-LT }\end{array}$ & $\begin{array}{l}\text { Group A: } 9 \% \\
\text { Group B: } 0 \%\end{array}$ \\
\hline Teegan, et al. ${ }^{83}$ & 352 & $\begin{array}{l}\text { Retrospective } \\
\text { analysis }\end{array}$ & LAM, ETV or TDF & $\begin{array}{l}10,000 \text { IU at anhepatic } \\
\text { phase followed by different } \\
\text { modes of prophylaxis }{ }^{2^{\mathrm{b}}}\end{array}$ & $\begin{array}{l}33.8 \% \text { in } \\
\text { patients } \\
\text { positive for } \\
\text { HBsAg at LT } \\
10.0 \% \text { in } \\
\text { patients } \\
\text { negative for } \\
\text { HBsAg at LT }\end{array}$ \\
\hline $\begin{array}{l}\text { Radhakrishnan, } \\
\text { et al. }\end{array}$ & 42 & $\begin{array}{l}\text { Retrospective } \\
\text { study }\end{array}$ & $\begin{array}{l}\text { TDF or ETV or TDF/ } \\
\text { FTC }\end{array}$ & $\begin{array}{l}5000 \text { IU in anhepatic phase } \\
\text { and daily for } 5 \text { days only }\end{array}$ & $\begin{array}{l}\text { Cumulative } \\
\text { recurrence at } 1 \text {, } \\
3 \text { and } 5 \text { years } \\
\text { was } 2.9 \%\end{array}$ \\
\hline Saab, et al. ${ }^{49}$ & 79 & $\begin{array}{l}\text { Retrospective } \\
\text { study }\end{array}$ & $\begin{array}{l}\text { LAM, ETV, TDF, TAF } \\
\text { and ADV used alone } \\
\text { or LAM + TDF or } \\
\text { ADV, ETV + TDF or } \\
\text { ADV }\end{array}$ & $\begin{array}{l}\text { Mean number of days from } \\
\text { LT to HBIg withdrawal: } 633 \\
\text { days (SD } \pm 552 \text { ) }\end{array}$ & $13.9 \%$ \\
\hline
\end{tabular}

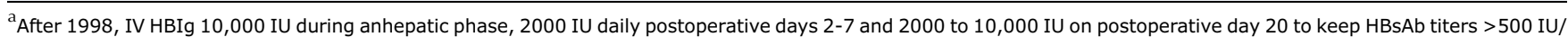
$\mathrm{mL}$, followed by $1560 \mathrm{IU}$ every $2-4$ weeks to keep titers $>500 \mathrm{IU} / \mathrm{mL}$ at $0-6$ months, $>250 \mathrm{IU} / \mathrm{mL}$ at $6-12 \mathrm{months}$ and $>100 \mathrm{IU} / \mathrm{mL}$ after $12 \mathrm{months}$.

${ }^{b} 12$ patients received no long-term prophylaxis, 97 received HBIg monoprophylaxis, 221 received HBIg+LAM, 22 received HBIg+ETV or TDF. Abbreviations: ADV, adefovir dipivoxil; ETV, entecavir; HBIg, hepatitis B immunoglobulin; HBsAb, hepatitis B surface antibody; HBV, hepatitis B virus; HDV, hepatitis D virus; IM, intramuscular; IV, intravenous; LAM, lamivudine; LT, liver transplant; NA, nucleos(t)ide analog; SD, standard deviation; TDF, tenofovir.

recurrence compared with recipients with positivity for viral markers. ${ }^{54,55}$ In fact, the risk of recurrence has been noted to be directly proportional to viral replication pre-LT. ${ }^{56} \mathrm{~A}$ retrospective study reported on 10 post-LT patients who initially received $\mathrm{HBIg}$ and NA but completely stopped it after a mean time from LT to withdrawal of around 24 months due to 


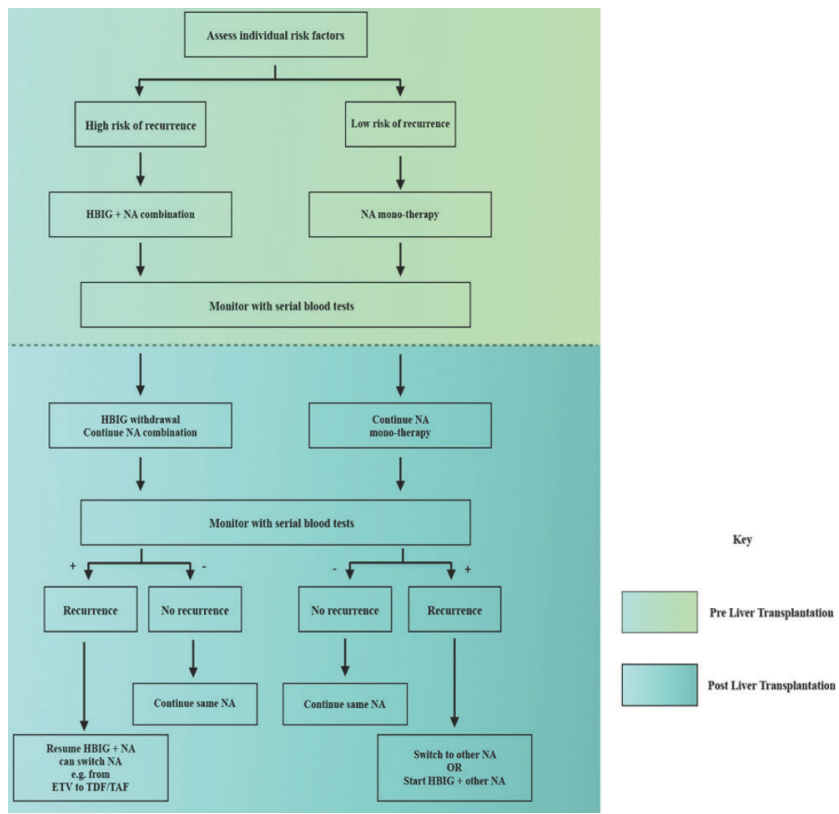

Fig. 3. An algorithm for suggested approach towards prevention and management of $\mathrm{HBV}$ recurrence in post-liver transplant patients.

Serial blood tests include those for hepatitis $s$ antigen ( $\mathrm{HBsAg}$ ) and HBV DNA. + refers to positive test result or detectable markers. - refers to negative test result or undetectable markers.

Abbreviations: DNA, deoxyribonucleic acid; ETV, entecavir; HBIG, hepatitis $B$ immune globulin; $\mathrm{HBsAg}$, hepatitis B surface antigen; HBV, hepatitis $B$ virus; NA, nucleoside analog; TAF, tenofovir alafenamide; TDF, tenofovir disoproxil fumarate.

non-adherence. They were followed for a mean of 52 months after withdrawal with monthly tests for HBV markers, including HBV DNA and liver function biomarkers. Out of 10 patients, 9 did not develop recurrence. ${ }^{56}$ It is important to note, however, that these nine patients tested negative for $\mathrm{HBeAg}$ and undetectable HBV DNA prior to LT and are considered 'low risk' for recurrence. They also maintained low tacrolimus levels $(<3 \mathrm{ng} / \mathrm{mL})$.

Tian et al. ${ }^{57}$ reported a case of complete prophylaxis withdrawal in a patient at high risk of recurrence, having $\mathrm{HBeAg}$ positivity and detectable HBV DNA at the time of liver transplantation. This patient received initial treatment with HBIg and ETV and then was maintained on this regimen as prophylaxis for recurrence. The patient stopped taking the prophylaxis for economic reasons after 3 years following the LT and was followed up with monthly tests for viral markers (HBsAg, HBeAg, HBV DNA) for 4 years; all remained negative and $\mathrm{HBsAb}$ remained positive. Interestingly, this patient also maintained low levels of tacrolimus (1-2 ng/mL). However, this data was published in a case report and larger studies are required to investigate the HBV recurrence rates with complete withdrawal of treatment.

Whereas the observations in the aforementioned studies are results of patient non-adherence, Lenci et al. ${ }^{58}$ employed a protocol with stepwise withdrawal of HBIg and NA. Thirty patients with positivity for HBsAg, negativity for HBV DNA, normal liver function and undetectable covalently closed circular DNA (cccDNA) in liver tissue, who received HBIg and NA since LT, were included. HBIg was withdrawn 6 months after the beginning of the screening phase and NA was withdrawn 6 months after withdrawal of the HBIg. Recurrence was noted in six $(20 \%)$ of the patients, five of which had an early recurrence (between 2-4 months of HBIg withdrawal). Out of these five patients, three did not require treatment due to spontaneous seroconversion to $\mathrm{HBsAb}$ within 4 months of recurrence and HBV DNA levels remained negative throughout. However, with extended follow-up of 6 years post-withdrawal, $60 \%$ of the patients had experienced seroconversion to HBsAg but only $10 \%$ required treatment and $100 \%$ were HBV DNA negative. Though this withdrawal strategy saved about $\$ 20,000$ per patient per year, it only applies to patients with low risk of recurrence. Larger studies are required to assess the safety and efficacy of withdrawal strategies.

\section{Role of active vaccination}

A single-center prospective study to investigate the efficacy and safety of active vaccination in patients was conducted, in which each patient was given double doses of the intramuscular vaccine at $0,1,2,6$ and 12 months of enrollment, with a follow up period of 6 months after completion of the vaccine protocol. ${ }^{59}$ Out of 27 men included in this study, 9 were responders $(33.3 \%)$. All the patients in this study were at least 1-year post-LT and were HBsAg- and HBV DNA-negative, with normal liver functions. They were all receiving $\mathrm{HBIg}$ and $\mathrm{NA}$, and $\mathrm{HBIg}$ was stopped after the vaccination protocol was complete at 12 months. They were followed for 6 months after completion of the vaccination protocol and HBIg withdrawal. Throughout the follow-up period, the patients maintained their HBsAg-negative status. Although this study suggests that active immunization in patients who receive LT due to HBV-related disease is feasible and allows for HBIg withdrawal, the low vaccine response rates, mainly because of immunosuppressed states of the post-LT hosts, has limited its use in this patient population. ${ }^{60,61}$

Ishigami et al. ${ }^{62}$ showed that frequent active vaccinations in post-LT patients can lead to production of escape mutants. This study included $18 \mathrm{HBV}$ carriers and 7 non-HBV carriers who were recipients of grafts from $\mathrm{HBcAb}$-positive donors. Of the 18 HBV carriers, 4 had detectable HBV DNA pre-LT. All patients received $\mathrm{HBIg}$ and $\mathrm{NA}$ and active vaccination was administered 1-year post-LT. Two of the HBV carriers and six of the non-HBV carriers were responders. In these patients, NAs were stopped after a successful vaccine response was obtained, and booster vaccinations were administered as needed. At a median of 12 months, two HBV carriers and two non-HBV carriers had detectable HBV DNA. Univariate analysis was done to investigate factors associated with viremia and frequent vaccination was found to be a significant risk factor. Moreover, amino acid sequencing showed several mutations, including the a-determinant in the HBV loop which plays an important role in the recognition of HBsAb proteins. Though this is a small study that only allowed for a univariate analysis, it cautions against NA withdrawal in HBV carriers and frequent vaccinations in post-LT patients. Larger prospective studies are required to establish the safety and efficacy of withdrawing HBIg and/or NAs in patients with prior HBV-related disease. Additionally, efforts should be made to improve the response rate of the vaccine. 
Nasir M. et al: HBV recurrence post-liver transplant

\section{Management of fulminant liver failure due to HBV} recurrence Post-LT

With the advent of newer NAs, the risk of fulminant liver failure due to recurrence of HBV after LT has been significantly reduced.

In the study by Zhang et al., 8 all 11 patients with HBV recurrence were on LAM, out of which 5 died. Four out of these five patients developed fulminant liver failure with jaundice and deteriorating liver function. The remaining six who survived were switched from LAM to either ADV or ADV/ETV combination in the early phases of recurrence, which resulted in improvement in their graft histology, including decreases in inflammation and hepatocyte swelling.

Roche et al. ${ }^{63}$ reported successful re-transplantation in five patients who experienced failure of LT due to HBV recurrence with the use of ganciclovir and HBIg combination. However, though this study demonstrates retransplantation as a feasible option in fulminant hepatic failure post-LT due to HBV recurrence, the antiviral regimen used in this study is only of historical value now with the advent of newer NAs, such as TDF/TAF and ETV.

\section{Prophylaxis of De Novo HBV infection from HBCAb- positive donors}

Studies have defined de novo HBV infection according to positive viral markers (HBsAg and detectable HBV DNA) after transplant in recipients who were negative for these markers pre-transplant. ${ }^{64,65}$ In the absence of prophylaxis, there was a high rate of HBV transmission from HBCAb-positive donors to HBsAg-negative recipients. ${ }^{6}$ It is presumed that livers from $\mathrm{HBCAb}$ positive donors may contain CcCDNA and pregenomic RNA in the hepatocyte nucleus which may result in de novo infection. ${ }^{66}$ However, given the scarcity of suitable liver grafts and the significant end-stage liver disease burden, HBCAb-positive donors have been used to expand the donor pool.

A cohort study in Italy suggested that transplant using $\mathrm{HBCAb}$-positive donors have comparatively favorable outcomes when the recipients were $\mathrm{HBsAg}$-positive, as opposed to HBsAg-negative, with the latter resulting in suboptimal graft quality. ${ }^{65}$ However, there are some important confounders that might explain this finding. The HBsAgpositive recipient group in this study had lower MELD scores, fewer recipients with concomitant $\mathrm{HCV}$ infection compared to the HBsAg-positive group, and the HBsAg-negative group received less rigorous prophylaxis.

On the contrary, a recent study conducted in China reported similar short-term and long-term outcomes using HBCAb-positive donors, irrespective of the HBsAg status of the recipients. ${ }^{64}$ All the patients received HBIg. Patients who were treated with HBIg monotherapy had a higher rate of de novo infection as compared with HBIg and NA combination. Multivariable adjustment and propensity-score matching was performed to equilibrate selection bias and potential confounders between study groups (HBCAb-positive and $\mathrm{HBcAb}$-negative recipients). Nevertheless, this is a retrospective study and is based in a single center, being subject to confounders and biases.

Wong et al. ${ }^{67}$ reported de novo infection in $4.7 \%$ of their studied patients who received LAM monotherapy while all patients receiving ETV monotherapy remained free of infection, likely due to a high resistance barrier with the latter. Recipients in the HBcAb-positive donor group had a graft survival of $\sim 77 \%$ versus $\sim 78 \%$ in the HBcAb-negative donor group, with almost no difference in patient survival between the two groups. They also proposed active immunization as a therapeutic form of management, which may render the need for prophylaxis unnecessary. Though this is a retrospective, single-center study, it involved a large cohort with a long follow-up time (median of 7.8 years).

Active immunization appears to be a promising strategy towards preventing de novo hepatitis $\mathrm{B}$ infection after $\mathrm{LT}$ from $\mathrm{HBCAb}$-positive donors. Ohno et al. ${ }^{68}$ used HBIg in the periand post-transplant period with multiple administrations of active $\mathrm{HBV}$ vaccination, with a target to maintain $\mathrm{HBsAb}$ levels $>300 \mathrm{mIU} / \mathrm{mL}$ for 1 year and $>100 \mathrm{mIU} / \mathrm{mL}$ subsequently. When the target was achieved without HBIg, active immunization was achieved. No patient tested positive for HBsAg or HBV DNA at 112 months after achieving active immunization. However, most of the fast responders in this

Table 3. Future drug targets for treatment of hepatitis $B$ infection

Therapies in Clinical Development

\begin{tabular}{|c|c|c|}
\hline Drug Class & Drug name & Mechanism of action \\
\hline Entry inhibitors & Bulevirtide & Inhibit viral entry by inhibiting NTCP, an HBV receptor ${ }^{75}$ \\
\hline RNA interference/siRNA & $\begin{array}{l}\text { ARC-520 } \\
\text { AB-729 }\end{array}$ & Bind to complementary mRNA, resulting in its elimination ${ }^{76}$ \\
\hline Core protein inhibitors & $\begin{array}{l}\text { AB-506 } \\
\text { RO7049389 }\end{array}$ & $\begin{array}{l}\text { Bind to hydrophobic pocket at dimer-dimer interface, resulting in allosteric } \\
\text { conformational changes in core protein with inability of nascent capsids to } \\
\text { encapsidate viral RNA }\end{array}$ \\
\hline TLR agonists & $\begin{array}{l}\text { GS-9620 (TLR } 7 \\
\text { agonist) } \\
\text { GS-9688 (TLR } 8 \\
\text { agonist) }\end{array}$ & $\begin{array}{l}\text { Trigger TLRs that result in production of antiviral cytokines (interferon- } \alpha \\
\text { and }-\gamma \text { ) and activation of natural killer and T cells }\end{array}$ \\
\hline \multicolumn{3}{|c|}{ Future drug targets (not enrolled in clinical trials yet) } \\
\hline PAPD5/7 inhibitors & \multicolumn{2}{|c|}{ Inhibit catalytic domains of PAPD5 and PAPD7 enzymes that result in destabilization of HBV mRNA ${ }^{72}$} \\
\hline Direct cccDNA targeting & & Use of zinc finger nucleases can directly edit $\mathrm{DNA}^{73,74}$ \\
\hline
\end{tabular}

Abbreviations: cccDNA, covalently closed circular DNA; HBV, hepatitis B virus; siRNA, small interfering ribonucleic acid; TLR, Toll-like receptor. 
study were in the pediatric population and the slow responders were mainly adults.

\section{Management of HBV infection from HBsAg-positive donors}

Wei et al. ${ }^{69}$ recruited 518 patients with HBV infection and divided them into two groups consisting of 259 patients each: one group received HBsAg-positive donor organ (observational) and one received HBsAg-negative donor organ (control). After LT, LAM, telbivudine, ETV and/or ADV were used for HBV treatment in both groups. The HBV recurrence rates at 1-year, 3-years and 5-years post-LT in the observational group versus the control group were $5.85 \%$ versus $1.97 \%$, $11.63 \%$ versus $4.46 \%$ and $17.94 \%$ versus $4.46 \%$, respectively $(p=0.016)$. However, when early stage complications (within 30 days post-LT; such as pleural effusion, postoperative infection and transplant graft dysfunction), long-term complications (more than 30 days post-LT; such as postoperative infection, rejection and vascular complications), and patient survival at 1-year, 3-years and 5-years post-LT were compared between the two groups, no significant difference was found. This study suggests that HBsAg-positive donors can be used with appropriate NA use. However, this was a retrospective study, including data from 2007 to 2012, during which time at least half the patients used LAM, which limits its applicability to current time with the advent of newer NAs. Prospective studies using newer antivirals are required to evaluate the HBV recurrence rate in patients receiving transplants from $\mathrm{HBsAg}$-positive donors.

Jeng et al. ${ }^{70}$ recruited 14 patients with HBV (HBsAg positivity) who received LT from HBsAg-positive donors. All patients received ETV, to be continued indefinitely. In the follow-up period (median of 46 months), two died in the $13^{\text {th }}$ and $33^{\text {rd }}$ month respectively due to extrahepatic recurrence of HCC but both had undetectable HBV DNA levels at year 1 . The rest of the patients maintained undetectable HBV DNA levels throughout the follow-up period. However, six of the fourteen recipients had undetectable HBV DNA levels prior to $L T$ and all patients continued to have HBsAg positivity despite undetectable HBV DNA levels in the follow-up period. Larger, randomized studies with control groups are required to validate the efficacy of use of ETV in managing $\mathrm{HBV}$ infection in LT recipients from $\mathrm{HBsAg}$-positive donors.

\section{Emerging drug targets and future directions}

The studies discussed above demonstrate NAs to be highly effective in preventing or managing HBV recurrence post-LT. However, their inability to inhibit cccDNA means that the replicative capacity is still present in the host nuclei. For the management of HBV, new drug targets, such as cccDNA, small interfering RNA-targeting viral transcripts, capsid assembly modulators and secretion of viral envelop proteins, are being proposed. ${ }^{71}$ Some are undergoing clinical development while others are being explored and have not entered trials yet (Table 3 ). However, it is important to note that these drugs are being assessed for the treatment of HBV and have yet to be tested for prevention of HBV recurrence post-LT.

Other drug targets are currently being explored that have not entered clinical trials yet. Mueller et al. ${ }^{72}$ found an RNA polymerase associated domain containing two proteins, PAPD5 and PAPD7 which are required for cellular RNA homeostasis. When RG7834, a potent HBV inhibitor belonging to the dihydroquinolizinone class, was made to interact with the two enzymes PAPD5 and PAPD7, destabilization and degradation of viral mRNA was seen. Technologies, such as CRISPR-Cas9 are now emerging that can directly edit DNA and can target ccCDNA directly. ${ }^{73,74}$ However, since these are non-clinical studies, it is unclear how potential drugs that directly target ccCDNA would have access to all infected cells. It is also unclear if these potential drugs may have capacity to cause mutations in the host DNA, which can possibly result in carcinogenesis.

Clinical trials are required to study the efficacy and safety of using these drugs for HBV management, including in patients who received LT.

\section{Conclusions}

The mainstay of management of hepatitis $B$ infection with prevention of its recurrence post-LT has been a combination of HBIg and NAs with high potency, such as TDF/TAF and ETV. However, other alternatives, such as combination therapy with HBIg withdrawal, HBIg monotherapy and NA monotherapy, have also been used with success. LT with anti-HBcAb-positive donors is now possible with the use of HBIg and NAs.

We suggest an individualized approach which takes patient risk factors, medication factors, cost and convenience into account (Fig. 3). For patients with high risk of recurrence, such as those with detectable HBV DNA levels at time of LT or known infection with resistant viral species pre-LT should receive HBIg for 6 months with a combination of NAs such as ETV and TDF/ TAF. NAs may need to be continued indefinitely, especially if the patient has human immunodeficiency virus or hepatitis $D$ virus co-infections. For patients at low risk of recurrence, such as those with undetectable HBV DNA levels at the time of LT, HBIg-free prophylaxis with NA monotherapy can be used. If ETV monotherapy fails, it can be switched to TDF monotherapy.

Further studies with larger patient populations are required to allow for better individualization of prophylactic protocols, which will allow for safe and cost-effective management of post-LT patients. Additionally, as noted in many studies mentioned in this review, many patients with $\mathrm{HBsAg}$ reappearance did not have detectable HBV DNA or deranged liver function or aminotransferases. This raises the question of the clinical significance of $\mathrm{HBsAg}$ positivity as a definition of $\mathrm{HBV}$ recurrence, raising the possible need to redefine HBV recurrence post-LT.

\section{Acknowledgements}

The support of the Herman Lopata Chair in Hepatitis is gratefully acknowledged.

\section{Funding}

None to declare.

\section{Conflict of interest}

The authors have no conflict of interests related to this publication.

\section{Author contributions}

Wrote and revised the review article (MN), edited the review article (GYW). 


\section{References}

[1] Puigvehí M, Hashim D, Haber PK, Dinani A, Schiano TD, Asgharpour A, et al. Liver transplant for hepatocellular carcinoma in the United States: Evolving trends over the last three decades. Am J Transplant 2020;20:220-230. doi: 10.1111/ajt.15576.

[2] Schilsky ML. Hepatitis B "360". Transplant Proc 2013;45:982-985. doi: 10. 1016/j.transproceed.2013.02.099.

[3] Buchanan C, Tran TT. Current status of liver transplantation for hepatitis B virus. Clin Liver Dis 2011;15:753-764. doi: 10.1016/j.cld.2011.08.011.

[4] Harmancõ Ö, Selçuk H, Haberal M. Prophylaxis against recurrence in liver transplantation patients with hepatitis B virus: What is new? J Clin Trans Hepatol 2014;2:259-265. doi: 10.14218/JCTH.2014.00023.

[5] Lee WC, Chou HS, Wu TH, Cheng CH, Lee CF, Wang YC, et al. Low-dose antihepatitis $\mathrm{B}$ immunoglobulin regimen as prophylaxis for hepatitis $\mathrm{B}$ recurrence after liver transplantation. Transpl Infect Dis 2019;21:e13190. doi: 10. $1111 /$ tid. 13190.

[6] Uemoto S, Sugiyama K, Marusawa H, Inomata $Y$, Asonuma K, Egawa $H$, et al. Transmission of hepatitis $\mathrm{B}$ virus from hepatitis $\mathrm{B}$ core antibody-positive donors in living related liver transplants. Transplantation 1998;65:494499. doi: 10.1097/00007890-199802270-00007.

[7] Lerut JP, Donataccio M, Ciccarelli O, Roggen F, Jamart J, Laterre PF, et al. Liver transplantation and $\mathrm{HBsAg}$-positive postnecrotic cirrhosis: adequate immunoprophylaxis and delta virus co-infection as the significant determinants of long-term prognosis. J Hepatol 1999;30:706-714. doi: 10.1016/s01688278(99)80203-7.

[8] Zhang D, Jiao Z, Han J, Cao H. Clinicopathological features of hepatitis B virus recurrence after liver transplantation: eleven-year experience. Int J Clin Exp Pathol 2014;7:4057-4066.

[9] Demetris AJ, Todo S, Van Thiel DH, Fung JJ, Iwaki Y, Sysyn G, et al. Evolution of hepatitis $B$ virus liver disease after hepatic replacement. Practical and theoretical considerations. Am J Pathol 1990;137:667-676.

[10] Song GW, Ahn CS, Lee SG, Hwang S, Kim KH, Moon DB, et al. Correlation between risk of hepatitis $B$ virus recurrence and tissue expression of covalently closed circular DNA in living donor liver transplant recipients treated with high-dose hepatitis B immunoglobulin. Transplant Proc 2014;46:35483553. doi: 10.1016/j.transproceed.2014.06.074.

[11] Devarbhavi HC, Cohen AJ, Patel R, Wiesner RH, Dickson RC, Ishitani MB. Preliminary results: outcome of liver transplantation for hepatitis $B$ virus varies by hepatitis B virus genotype. Liver Transpl 2002;8:550-555. doi: $10.1053 /$ jlts.2002.33483.

[12] Jiang Z, Feng X, Zhang W, Gao F, Ling Q, Zhou L, et al. Recipient cytotoxic T lymphocyte antigen- $4+49 \mathrm{G} / \mathrm{G}$ genotype is associated with reduced incidence of hepatitis $\mathrm{B}$ virus recurrence after liver transplantation among Chinese patients. Liver Int 2007;27:1202-1208. doi: $10.1111 / \mathrm{j} .1478$ 3231.2007.01553.x.

[13] Ferrari TC, Xavier MA, Vidigal PV, Amaral NS, Diniz PA, Resende AP, et al. Occult hepatitis $B$ virus infection in liver transplant patients in a Brazilian referral center. Braz J Med Biol Res 2014;47:990-994. doi: 10.1590/1414$431 \times 20143782$.

[14] Perrillo RP. Acute flares in chronic hepatitis B: the natural and unnatura history of an immunologically mediated liver disease. Gastroenterology 2001;120:1009-1022. doi: 10.1053/gast.2001.22461.

[15] Cheng AL, Hsiung CA, Su IJ, Chen PJ, Chang MC, Tsao CJ, et al. Steroid-free chemotherapy decreases risk of hepatitis $B$ virus (HBV) reactivation in HBVcarriers with lymphoma. Hepatology 2003;37:1320-1328. doi: 10 . 1053/jhep.2003.50220.

[16] Gonzalez SA. Hepatitis B virus. Antimicrobe. Available from: http://www. antimicrobe.org/v22.asp\#tab5.

[17] Pollicino T, Raimondo G. Occult hepatitis B infection. J Hepatol 2014;61:688689. doi: 10.1016/j.jhep.2014.04.036

[18] Samal J, Kandpal M, Vivekanandan P. Molecular mechanisms underlying occult hepatitis B virus infection. Clin Microbiol Rev 2012;25:142-163. doi: 10.1128/CMR.00018-11.

[19] Shouval D, Samuel D. Hepatitis B immune globulin to prevent hepatitis B virus graft reinfection following liver transplantation: a concise review. Hepatology 2000;32:1189-1195. doi: 10.1053/jhep.2000.19789.

[20] Schilling R, Ijaz S, Davidoff M, Lee JY, Locarnini S, Williams R, et al. Endocytosis of hepatitis $B$ immune globulin into hepatocytes inhibits the secretion of hepatitis B virus surface antigen and virions. J Virol 2003;77:8882-8892. doi: $10.1128 /$ jvi.77.16.8882-8892.2003.

[21] McGory RW, Ishitani MB, Oliveira WM, Stevenson WC, McCullough CS, Dickson RC, et al. Improved outcome of orthotopic liver transplantation for chronic hepatitis $\mathrm{B}$ cirrhosis with aggressive passive immunization. Transplantation 1996;61:1358-1364. doi: 10.1097/00007890-19960515000013.

[22] Samuel D, Muller R, Alexander G, Fassati L, Ducot B, Benhamou JP, et al. Liver transplantation in European patients with the hepatitis $B$ surface antigen. N Engl J Med 1993;329:1842-1847. doi: 10. 1056/NEJM199312163292503.

[23] Markowitz JS, Martin P, Conrad AJ, Markmann JF, Seu P, Yersiz H, et al. Prophylaxis against hepatitis $\mathrm{B}$ recurrence following liver transplantation using combination lamivudine and hepatitis B immune globulin. Hepatology 1998; 28:585-589. doi: 10.1002/hep.510280241.

[24] Carman WF, Trautwein C, van Deursen FJ, Colman K, Dornan E, McIntyre G, et al. Hepatitis $\mathrm{B}$ virus envelope variation after transplantation with and without hepatitis B immune globulin prophylaxis. Hepatology 1996;24: 489-493. doi: 10.1002/hep.510240304.

[25] Ghany MG, Ayola B, Villamil FG, Gish RG, Rojter S, Vierling JM, et al. Hepatitis $B$ virus $S$ mutants in liver transplant recipients who were reinfected despite hepatitis B immune globulin prophylaxis. Hepatology 1998;27:213-222. doi: $10.1002 /$ hep.510270133.

[26] Terrault NA, Zhou S, Combs C, Hahn JA, Lake JR, Roberts JP, et al. Prophylaxis in liver transplant recipients using a fixed dosing schedule of hepatitis $B$ immunoglobulin. Hepatology 1996;24:1327-1333. doi: 10.1002/hep. 510240601.

[27] Carman WF, Zanetti AR, Karayiannis P, Waters J, Manzillo G, Tanzi E, et al. Vaccine-induced escape mutant of hepatitis B virus. Lancet 1990;336:325329. doi: 10.1016/0140-6736(90)91874-a.

[28] Bielen R, Robaeys G, Schelfhout S, Monbaliu D, Van der Merwe S, Pirenne ], et al. Personalized subcutaneous administration of hepatitis B surface antibodies without nucleos(t)ide analogs for patients at risk of renal failure after liver transplantation: a prospective single center cohort study. Transpl Int 2018;31:503-509. doi: 10.1111/tri.13112.

[29] Roche B, Roque-Afonso AM, Nevens F, Samuel D. Rational basis for optimizing short and long-term hepatitis $B$ virus prophylaxis post liver transplantation: Role of hepatitis B immune globulin. Transplantation 2015;99:13211334. doi: 10.1097/TP.0000000000000777.

[30] Lowell JA, Burgess S, Shenoy S, Curci JA, Peters M, Howard TK. Mercury poisoning associated with high-dose hepatitis-B immune globulin administration after liver transplantation for chronic hepatitis B. Liver Transpl Surg 1996;2:475-478. doi: 10.1002/It.500020612.

[31] Mutimer D, Pillay D, Dragon E, Tang H, Ahmed M, O'Donnell K, et al. High pretreatment serum hepatitis $B$ virus titre predicts failure of lamivudine prophylaxis and graft re-infection after liver transplantation. J Hepatol 1999;30: 715-721. doi: 10.1016/s0168-8278(99)80204-9.

[32] Perrillo RP, Wright T, Rakela J, Levy G, Schiff E, Gish R, et al. A multicenter United States-Canadian trial to assess lamivudine monotherapy before and after liver transplantation for chronic hepatitis B. Hepatology 2001;33:424432. doi: 10.1053/jhep.2001.21554.

[33] Yao FY, Osorio RW, Roberts JP, Poordad FF, Briceno MN, Garcia-Kennedy R, et al. Intramuscular hepatitis $B$ immune globulin combined with lamivudine for prophylaxis against hepatitis $B$ recurrence after liver transplantation. Liver Transpl Surg 1999;5:491-496. doi: 10.1002/lt.500050605.

[34] Yoshida EM, Erb SR, Partovi N, Scudamore CH, Chung SW, Frighetto L, et al. Liver transplantation for chronic hepatitis $B$ infection with the use of combination lamivudine and low-dose hepatitis B immune globulin. Liver Transpl Surg 1999;5:520-525. doi: 10.1002/It.500050602.

[35] Marzano A, Salizzoni M, Debernardi-Venon W, Smedile A, Franchello A Ciancio $A$, et al. Prevention of hepatitis $B$ virus recurrence after liver transplantation in cirrhotic patients treated with lamivudine and passive immunoprophylaxis. J Hepatol 2001;34:903-910. doi: 10.1016/s0168-8278(01) 00080-0.

[36] Samuel D. Liver transplantation and hepatitis B virus infection: the situation seems to be under control, but the virus is still there. J Hepatol 2001;34: 943-945. doi: 10.1016/s0168-8278(01)00102-7.

[37] Beckebaum S, Herzer K, Bauhofer A, Gelson W, De Simone P, de Man R, et al. Recurrence of hepatitis $B$ infection in liver transplant patients receiving longterm hepatitis B immunoglobulin prophylaxis. Ann Transplant 2018;23:789801. doi: 10.12659/AOT.910176.

[38] Corrigendum to: "EASL clinical practice guidelines: Management of chronic hepatitis B virus infection" [J Hepatol 2012;57:167-185]. J Hepatol 2013; 58:P201. doi: 10.1016/j.jhep.2012.09.013.

[39] Cholongitas E, Goulis J, Akriviadis E, Papatheodoridis GV. Hepatitis B immunoglobulin and/or nucleos(t)ide analogues for prophylaxis against hepatitis $b$ virus recurrence after liver transplantation: a systematic review. Liver Transpl 2011;17:1176-1190. doi: 10.1002/lt.22354.

[40] Cholongitas E, Papatheodoridis GV. High genetic barrier nucleos(t)ide analogue(s) for prophylaxis from hepatitis B virus recurrence after liver transplantation: a systematic review. Am J Transplant 2013;13:353-362. doi: 10. 1111/j.1600-6143.2012.04315.x

[41] Terrault NA, Lok ASF, McMahon BJ, Chang KM, Hwang JP, Jonas MM, et al. Update on prevention, diagnosis, and treatment of chronic hepatitis $B$ : AASLD 2018 hepatitis B guidance. Hepatology 2018;67:1560-1599. doi: 10.1002/hep.29800

[42] Darweesh SK, Gad AA, Akroof K, ElLatif ZA. Entecavir and other nucleos(t)ide analogs prophylaxis in hepatitis $B$ virus-related liver transplantation: long- 
term efficacy and safety. Eur J Gastroenterol Hepatol 2019;31:607-612. doi: 10.1097/MEG.0000000000001377.

[43] Shen S, Jiang L, Xiao GQ, Yan LN, Yang JY, Wen TF, et al. Prophylaxis against hepatitis B virus recurrence after liver transplantation: a registry study. World J Gastroenterol 2015;21:584-592. doi: 10.3748/wjg.v21.i2.584.

[44] Lucey MR, Terrault N, Ojo L, Hay JE, Neuberger J, Blumberg E, et al. Longterm management of the successful adult liver transplant: 2012 practice guideline by the American Association for the Study of Liver Diseases and the American Society of Transplantation. Liver Transpl 2013;19:3-26. doi: 10.1002/lt.23566.

[45] Sarin SK, Kumar M, Lau GK, Abbas Z, Chan HL, Chen CJ, et al. Asian-Pacific clinical practice guidelines on the management of hepatitis B: a 2015 update. Hepatol Int 2016;10:1-98. doi: 10.1007/s12072-015-9675-4

[46] EASL 2017 Clinical Practice Guidelines on the management of hepatitis B. virus infection. J Hepatol 2017;67:370-398. doi: 10.1016/j.jhep.2017.03. 021.

[47] Saab S, Desai S, Tsaoi D, Durazo F, Han S, McClune A, et al. Posttransplantation hepatitis $B$ prophylaxis with combination oral nucleoside and nucleotide analog therapy. Am J Transplant 2011;11:511-517. doi: 10.1111/j. 1600-6143.2010.03416.x.

[48] Dan YY, Wai CT, Yeoh KG, Lim SG. Prophylactic strategies for hepatitis B patients undergoing liver transplant: a cost-effectiveness analysis. Liver Transpl 2006;12:736-746. doi: 10.1002/lt.20685.

[49] Saab S, Song D, Challita YP, Xiwen Zhou T, Saab EG, Viramontes MR, et al. Long-term outcomes with oral therapy in liver transplant recipients with hepatitis B. Clin Transplant 2019;33:e13740. doi: 10.1111/ctr.13740.

[50] Gane EJ, Patterson S, Strasser SI, McCaughan GW, Angus PW. Combination of lamivudine and adefovir without hepatitis B immune globulin is safe and effective prophylaxis against hepatitis $B$ virus recurrence in hepatitis $B$ surface antigen-positive liver transplant candidates. Liver Transpl 2013;19: 268-274. doi: 10.1002/It.23600.

[51] Stravitz RT, Shiffman ML, Kimmel M, Puri P, Luketic VA, Sterling RK, et al. Substitution of tenofovir/emtricitabine for Hepatitis B immune globulin prevents recurrence of Hepatitis B after liver transplantation. Liver Int 2012;32: 1138-1145. doi: 10.1111/j.1478-3231.2012.02770.x.

[52] Fung J, Wong T, Chok K, Chan A, Cheung T, Dai JW, et al. Long-term outcomes of entecavir monotherapy for chronic hepatitis $B$ after liver transplantation: Results up to 8 years. Hepatology 2017;66:1036-1044. doi: 10 . 1002/hep.29191.

[53] Zheng JN, Zou TT, Zou H, Zhu GQ, Ruan LY, Cheng Z, et al. Comparative efficacy of oral nucleotide analogues for the prophylaxis of hepatitis $B$ virus recurrence after liver transplantation: a network meta-analysis. Expert Rev Anti Infect Ther 2016;14:979-987. doi: 10.1080/14787210.2016.1220831.

[54] Neff GW, O'brien CB, Nery J, Shire N, Montalbano M, Ruiz P, et al. Outcomes in liver transplant recipients with hepatitis $B$ virus: resistance and recurrence patterns from a large transplant center over the last decade. Liver Transp 2004;10:1372-1378. doi: 10.1002/It.20277.

[55] Degertekin B, Han SH, Keeffe EB, Schiff ER, Luketic VA, Brown RS Jr, et al. Impact of virologic breakthrough and HBIG regimen on hepatitis $B$ recurrence after liver transplantation. Am J Transplant 2010;10:1823-1833. doi: $10.1111 / j .1600-6143.2010 .03046 . x$.

[56] Geng L, Lin BY, Shen T, Guo H, Ye YF, Zheng SS. Anti-virus prophylaxis withdrawal may be feasible in liver transplant recipients whose serum HBeAg and HBV DNA are negative. Hepatobiliary Pancreat Dis Int 2016;15:316-318. doi: 10.1016/s1499-3872(16)60087-5.

[57] Shen T, Ye Y, Geng L, Zheng S. Complete withdrawal of hepatitis B virus prophylaxis after liver transplantation in a recipient at high risk of recurrence. Int J Clin Exp Med 2015;8:8238-8240.

[58] Lenci I, Baiocchi L, Tariciotti L, Di Paolo D, Milana M, Santopaolo F, et al. Complete hepatitis $B$ virus prophylaxis withdrawal in hepatitis B surface antigen-positive liver transplant recipients after longterm minimal immunosuppression. Liver Transpl 2016;22:1205-1213. doi: 10.1002/It.24493.

[59] Yang A, Guo Z, Ren Q, Wu L, Ma Y, Hu A, et al. Active immunization in patients transplanted for hepatitis $B$ virus related liver diseases: A prospective study. PLoS One 2017;12:e0188190. doi: 10.1371/journal.pone.0188190.

[60] Sánchez-Fueyo A, Rimola A, Grande L, Costa J, Mas A, Navasa M, et al. Hepatitis $B$ immunoglobulin discontinuation followed by hepatitis $B$ virus vaccination: A new strategy in the prophylaxis of hepatitis $B$ virus recurrence after liver transplantation. Hepatology 2000;31:496-501. doi: 10. 1002/hep.510310233.

[61] Rosenau J, Hooman N, Rifai K, Solga T, Tillmann HL, Grzegowski E, et al. Hepatitis $B$ virus immunization with an adjuvant containing vaccine after liver transplantation for hepatitis B-related disease: failure of humoral and cellular immune response. Transpl Int 2006;19:828-833. doi: 10.1111/j. 1432-2277.2006.00374.X

[62] Ishigami M, Honda T, Ishizu $Y$, Onishi $Y$, Kamei $H$, Hayashi $K$, et al. Frequent incidence of escape mutants after successful hepatitis $B$ vaccine response and stopping of nucleos(t)ide analogues in liver transplant recipients. Liver Transpl 2014;20:1211-1220. doi: 10.1002/It.23935.
[63] Roche B, Samuel D, Feray C, Majno P, Gigou M, Reynes M, et al. Retransplantation of the liver for recurrent hepatitis $B$ virus infection: the Paul Brousse experience. Liver Transpl Surg 1999;5:166-174. doi: 10.1002/It. 500050304

[64] Lei M, Yan LN, Yang JY, Wen TF, Li B, Wang WT, et al. Safety of hepatitis B virus core antibody-positive grafts in liver transplantation: A single-center experience in China. World J Gastroenterol 2018;24:5525-5536. doi: 10. 3748/wjg.v24.i48.5525.

[65] Angelico M, Nardi A, Marianelli T, Caccamo L, Romagnoli R, Tisone G, et al. Hepatitis B-core antibody positive donors in liver transplantation and their impact on graft survival: evidence from the Liver Match cohort study. J Hepatol 2013;58:715-723. doi: 10.1016/j.jhep.2012.11.025.

[66] Raimondo G, Allain JP, Brunetto MR, Buendia MA, Chen DS, Colombo M, et al. Statements from the Taormina expert meeting on occult hepatitis $B$ virus infection. J Hepatol 2008;49:652-657. doi: 10.1016/j.jhep.2008.07.014.

[67] Wong TC, Fung JY, Cui TY, Lam AH, Dai JW, Chan AC, et al. Liver transplantation using hepatitis $\mathrm{B}$ core positive grafts with antiviral monotherapy prophylaxis. J Hepatol 2019;70:1114-1122. doi: 10.1016/j.jhep.2019.03.003.

[68] Ohno Y, Mita A, Ikegami T, Masuda Y, Urata K, Nakazawa Y, et al. Successfu active immunization using a hepatitis $B$ virus vaccination protocol for a recipient with hepatitis B core antibody-positive liver graft. Transplant Proc 2014; 46:721-725. doi: 10.1016/j.transproceed.2013.12.005.

[69] Wei L, Chen D, Zhang B, Zhao Y, Liu B, Shi H, et al. Long-term outcome and recurrence of hepatitis $B$ virus following liver transplantation from hepatitis $B$ surface antigen-positive donors in a Chinese population. J Viral Hepat 2018; 25:1576-1581. doi: 10.1111/jvh.12972.

[70] Jeng LB, Thorat A, Yang HR, Yeh CC, Chen TH, Hsu CH, et al. Successful use of hepatitis B surface antigen-positive liver grafts - an effective source for donor organs in endemic areas: a single-center experience. Ann Transplant 2015;20:103-111. doi: 10.12659/AOT.893032.

[71] Durantel D, Zoulim F. New antiviral targets for innovative treatment concepts for hepatitis B virus and hepatitis delta virus. J Hepatol 2016;64:S117-S131. doi: $10.1016 /$ j.jhep.2016.02.016.

[72] Mueller H, Lopez A, Tropberger P, Wildum S, Schmaler J, Pedersen L, et al. PAPD5/7 are host factors that are required for hepatitis B virus RNA stabilization. Hepatology 2019;69:1398-1411. doi: 10.1002/hep.30329.

[73] Kennedy EM, Bassit LC, Mueller H, Kornepati AVR, Bogerd HP, Nie T, et al. Suppression of hepatitis $B$ virus DNA accumulation in chronically infected cells using a bacterial CRISPR/Cas RNA-guided DNA endonuclease. Virology 2015;476:196-205. doi: 10.1016/j.virol.2014.12.001.

[74] Kennedy EM, Kornepati AV, Cullen BR. Targeting hepatitis B virus cccDNA using CRISPR/Cas9. Antiviral Res 2015;123:188-192. doi: 10.1016/j.antiviral.2015.10.004.

[75] Urban S, Bartenschlager R, Kubitz R, Zoulim F. Strategies to inhibit entry of HBV and HDV into hepatocytes. Gastroenterology 2014;147:48-64. doi: 10 1053/j.gastro.2014.04.030.

[76] Chen Y, Cheng G, Mahato RI. RNAi for treating hepatitis B viral infection. Pharm Res 2008;25:72-86. doi: 10.1007/s11095-007-9504-0.

[77] Zhang X, Cheng J, Ma J, Hu Z, Wu S, Hwang N, et al. Discovery of novel hepatitis B virus nucleocapsid assembly inhibitors. ACS Infect Dis 2019;5 759-768. doi: 10.1021/acsinfecdis.8b00269.

[78] Ma Z, Cao Q, Xiong Y, Zhang E, Lu M. Interaction between hepatitis B virus and toll-like receptors: Current status and potential therapeutic use for chronic hepatitis B. Vaccines (Basel) 2018;6:E6. doi: 10 3390/vaccines6010006.

[79] Boni C, Vecchi A, Rossi M, Laccabue D, Giuberti T, Alfieri A, et al. TLR7 agonist increases responses of hepatitis $B$ virus-specific T cells and natural killer cells in patients with chronic hepatitis B treated with nucleos(t)ide analogues. Gastroenterology 2018;154:1764-1777.e7. doi: 10.1053/j.gastro.2018. 01.030 .

[80] Vasudevan A, Ardalan ZS, Ahmed N, Apostolov R, Gow PJ, Testro AG, et al. Long-term safety and efficacy of tenofovir disoproxil fumarate substitution for hepatitis B immunoglobulin following liver transplantation. JGH Open 2018;2:288-294. doi: 10.1002/jgh3.12086.

[81] Lens S, García-Eliz M, Fernández I, Castells L, Bonacci M, Mas A, et al. Shorter hepatitis B immunoglobulin administration is not associated to hepatitis $B$ virus recurrence when receiving combined prophylaxis after live transplantation. Liver Int 2018;38:1940-1950. doi: 10.1111/liv.13858.

[82] Manini MA, Whitehouse G, Bruce M, Passerini M, Lim TY, Carey I, et al. Entecavir or tenofovir monotherapy prevents HBV recurrence in liver transplant recipients: A 5-year follow-up study after hepatitis B immunoglobulin withdrawal. Dig Liver Dis 2018;50:944-953. doi: 10.1016/j.dld.2018.03.032.

[83] Teegen EM, Maurer MM, Globke B, Pratschke J, Eurich D. Liver transplantation for Hepatitis-B-associated liver disease - Three decades of experience. Transpl Infect Dis 2019;21:e12997. doi: 10.1111/tid.12997.

[84] Radhakrishnan K, Chi A, Quan DJ, Roberts JP, Terrault NA. Short course of postoperative hepatitis $B$ immunoglobulin plus antivirals prevents reinfection of liver transplant recipients. Transplantation 2017;101:2079-2082. doi: 10.1097/TP.0000000000001786. 